\title{
Selective recruitment of breast cancer anti-estrogen resistance genes and relevance for breast cancer progression and tamoxifen therapy response
}

\author{
Ton van Agthoven ${ }^{1}$, Anieta M Sieuwerts ${ }^{2}$, Danielle Meijer ${ }^{1}$, \\ Marion E Meijer-van Gelder ${ }^{2}$, Thecla $L$ A van Agthoven ${ }^{1}$, Roya Sarwari', \\ Stefan Sleijfer ${ }^{2}$, John A Foekens ${ }^{2,3}$ and Lambert C J Dorssers ${ }^{1}$ \\ ${ }^{1}$ Department of Pathology, ${ }^{2}$ Department of Medical Oncology and ${ }^{3}$ Cancer Genomics Center, Josephine Nefkens Institute, \\ Erasmus MC - University Medical Center Rotterdam, Be432, Erasmus MC. PO Box 2040, 3000 CA Rotterdam, The Netherlands \\ (Correspondence should be addressed to L C J Dorssers; Email: I.dorssers@erasmusmc.nl)
}

\begin{abstract}
Although endocrine treatment of breast cancer is effective and common practice, in advanced disease the development of resistance is nearly inevitable. To get more insight into individual genes that account for resistance against hormonal agents, we have executed functional genetic screens and subsequently evaluated the clinical relevance of several identified genes with respect to tumor aggressiveness and tamoxifen resistance in estrogen receptor-positive patients. Estrogen-dependent human breast cancer cells were transduced with different retroviral cDNA expression libraries and subjected to selective cultures with various anti-estrogens. From a total of 264 resistant cell clones, 132 different genes were recovered by PCR. By applying stringent selection criteria, we identified 15 breast cancer anti-estrogen resistance $(B C A R)$ genes individually yielding resistance. $B C A R$ genes were recovered with differential frequencies for the diverse culture conditions and anti-estrogen drugs. Analysis of the relation of $B C A R$ genes (EIF1, FBXL10, HRAS, NRG1, PDGFRA, PDGFRB, RAD21, and RAF1) with tamoxifen treatment in patients with advanced disease showed significant association with clinical benefit and progression-free survival for EIF1 and PDGFRA mRNA levels. Furthermore, PDGFRA and HRAS mRNA levels were significantly associated with tumor aggressiveness in lymph node-negative patients who had not received adjuvant systemic therapy. In conclusion, our functional genetic screens showed that $B C A R$ genes differ in their ability to confer resistance towards distinct antiestrogens. Based on the clinical relevance of several BCAR genes, further studies are warranted to characterize the underlying mechanisms, which may ultimately lead to the development of novel treatments and more individualized management of breast cancer patients.
\end{abstract}

Endocrine-Related Cancer (2010) 17 215-230

\section{Introduction}

Estrogens play important roles in the establishment and progression of breast cancer. As a consequence, endocrine treatment modalities have been designed to counter the supportive role of estrogens in breast cancer. In the past decades, the anti-estrogen tamoxifen has become a cornerstone in the treatment of estrogen receptor (ER)-positive breast cancer. Large clinical trials have proven its beneficial effects in the adjuvant treatment of localized disease (Early Breast Cancer Trialists' Collaborative Group 2005), in the prevention of breast cancer in high risk women (Cuzick et al. 2007), and in the metastatic setting. However, in metastatic disease, $\sim 30-40 \%$ of the patients with $\mathrm{ER} \alpha$-positive tumors fail to respond to tamoxifen treatment due to intrinsic or de novo resistance of the tumor. Furthermore, in nearly all patients initially showing a response to tamoxifen, progressive disease 
(PD) will ultimately develop while still on treatment (Jaiyesimi et al. 1995, Jordan 1995). To improve outcomes of hormonal therapy and to attenuate the side effects accompanying tamoxifen therapy such as increased risks of endometrial cancer and thromboembolic events (Early Breast Cancer Trialists' Collaborative Group 1998), several other antiestrogens have been developed including selective ER modulators, selective ER down-regulator (Lerner \& Jordan 1990, Howell et al. 2004), and aromatase inhibitors, the latter blocking the conversion of androgens into estrogens. In recent years, several of these novel drugs have been shown superior to tamoxifen in randomized clinical trials and, consequently, have replaced tamoxifen in various settings (Howell et al. 2004, Howell 2005, Johnston 2005, Come et al. 2008). However, similar to tamoxifen, the development of resistance to these new drugs seems inevitable. The mechanistic basis for the resistant phenotype is thought to originate from the various aspects of estrogen signaling, the interaction with co-regulators, and the interplay with growth factor signaling (Dorssers et al. 2001, Ali \& Coombes 2002, Clarke et al. 2003, Gutierrez et al. 2005, Nicholson et al. 2005, Osborne \& Schiff 2005, Riggins et al. 2007, Hurtado et al. 2008, Iorns et al. 2008, Zwart et al. 2009). In spite of the considerable progress made in the last decades, we still do not comprehend the complete spectrum of resistance mechanisms, and detailed study of different models may help to resolve these options.

In recent years, we have used functional genetic screens to identify individual genes that contribute to or are responsible for resistance to anti-estrogens. Our first approach was based on insertional mutagenesis by targeting cells with defective retroviruses. The integration of virus can affect an individual gene and thereby altering the cell phenotype (Dorssers et al. 1993). Through this approach, seven breast cancer anti-estrogen resistance $(B C A R)$ genes responsible for the transition of an estrogen-dependent, tamoxifen-sensitive human breast cancer cell line into a tamoxifen-resistant phenotype have been elucidated (Van Agthoven et al. 1998, 2009b, Brinkman et al. 2000). In view of the complexity and the workload of this approach, we have recently tested retroviral transduction of cDNA expression libraries (Brummelkamp \& Bernards 2003) as an alternative strategy. In these experiments, the coding sequences of numerous genes present in the library are introduced into target cells by means of retroviral infection. Cells that acquired a gene product enabling growth in the presence of drugs can be recovered and the gene conferring resistance can be identified through PCR.
Through applying this technique with the breast cancer cell line ZR-75-1, we have previously identified a set of seven $B C A R$ genes conferring resistance to tamoxifen (Meijer et al. 2006). In the present study, we explored whether the use of an additional target cell line, an additional cDNA library, and different selective culture conditions using several anti-estrogens would reveal novel $B C A R$ genes. Furthermore, novel BCAR genes identified through this approach were assessed for their clinical relevance in terms of tamoxifen resistance and tumor aggressiveness.

\section{Materials and methods}

\section{Cell lines and transduction experiments}

ZR-75-1 cells were cultured in RPMI 1640 medium (Invitrogen) supplemented with $10 \%$ heat-inactivated bovine calf serum (standard medium) (Hyclone, Logan, UT, USA) and with $1 \mathrm{nM} 17 \beta$-estradiol (SigmaAldrich) as described previously (Van Agthoven et al. 1992). MCF-7 cells were cultured in RPMI medium supplemented with $10 \%$ FCS (Sigma-Aldrich) as described (Van Agthoven et al. 1998). Retroviral transduction experiments were performed using retroviral cDNA expression libraries derived from human placenta, human brain, mouse embryo, and HELA cells, a cervical cancer cell line (Clontech). Cell-free supernatants containing viral particles were produced and used for infection experiments as detailed previously (Meijer et al. 2006). Cell colonies resistant to anti-estrogens $(1 \mu \mathrm{M}$ 4-hydroxytamoxifen (OH-TAM, Sigma-Aldrich), $1 \mu \mathrm{M}$ raloxifene (raloxifene hydrochloride, Sigma-Aldrich), or $100 \mathrm{nM}$ ICI 182780 (Zeneca Pharmaceuticals, Macclesfield, UK)) were picked and expanded in standard medium supplemented with $10 \%$ conditioned medium of CRIP cells (mouse fibroblast cell line) and the respective anti-estrogen (Dorssers et al. 1993). Soft agar colony assays in the presence of OH-TAM were performed as described (Meijer et al. 2006).

\section{Analysis of proviral cDNA inserts}

Integrated cDNAs were retrieved from genomic DNA by PCR using primers located adjacent to the cDNA cloning site and sequenced on an ABI PRISM 3100 Genetic Analyzer (Applied Biosystems, Nieuwerkerk a/d IJssel, The Netherlands) using ABI PRISM BigDye Terminators v3.0 Cycle Sequencing Kits (Applied Biosystems) according to the protocols of the manufacturers as described (Meijer et al. 2006). The cDNAs were identified by sequence similarity searches 
using Basic Local Alignment Search Tools (http:// blast.ncbi.nlm.nih.gov/Blast.cgi).

\section{Expression constructs and proliferation assays}

cDNA clones of $H R A S$ and RAFl were recovered from the resistant cell lines and sequenced. The coding regions of HRAS (corresponding to nt 11 to 1029 of NM_005343.2), RAF1 (nt 883 to 2489 of NM_002880), PDGFRA (NM_006206), and PDGFRB (NM_002609.1) were cloned into the LZRS-IRES-Neo expression vector and introduced into ZR-75-1 cells as described (Meijer et al. 2006, Van Agthoven et al. $2009 b$ ). Two independently generated pools of cells were assayed for anti-estrogen resistance in 96-well plates using the WST-1 reagent (Roche Diagnostics) according to the recommendation of the supplier.

\section{Patients}

The protocol to study biological markers associated with disease outcome was approved by the medical ethics committee of the Erasmus Medical Center Rotterdam, The Netherlands (MEC 02.953). This retrospective study used 691 blind coded, ER proteinpositive ( $\geq 10 \mathrm{fmol} / \mathrm{mg}$ protein) primary tumor tissues, in accordance with the Code of Conduct of the Federation of Medical Scientific Societies in The Netherlands (http://www.fmvv.nl) and, wherever possible, has been reported in line with the REMARK guidelines (McShane et al. 2006). The primary breast tumors were from patients with detailed clinical followup as previously described (Van Agthoven et al. 2009a). All patients underwent breast surgery from 1979 to 1996 . ER status was determined by routine ligand-binding assays or enzyme immunoassays (Foekens et al. 1989). For the study of tamoxifen resistance, ER-positive primary tumors of both lymph node-negative (LNN) and -positive patients were selected. Tumor aggressiveness was evaluated in LNN patients with ER-positive primary tumors who had not received any adjuvant systemic treatment.

To evaluate the relationship of individual $B C A R$ genes with tamoxifen resistance, 289 patients who received tamoxifen monotherapy as first-line treatment for advanced disease were included. Of these patients, 29 presented with distant metastasis at diagnosis. Of the remaining patients, none $(41 \%$ were node negative) had received adjuvant hormone therapy, and 54 patients were treated with systemic adjuvant chemotherapy (20 with anthracycline and 34 with nonanthracycline-based regimens). Response to tamoxifen treatment was monitored according to standardized protocol (Hayward et al. 1977, EORTC
Breast Cancer Cooperative Group 2000) as detailed previously (Van Agthoven et al. 2009a). Clinical benefit defined as objective response or stable disease (SD) for more than 6 months was achieved by 178 patients $(61.6 \%)$ with 13 complete remissions, 38 partial remissions, and $127 \mathrm{SD}$ for more than 6 months. No clinical benefit was observed for 111 patients (93 PD and 18 SD for 6 months or less). The median time to progression was 8.2 months. Median followup after start of therapy of patients alive at the end of the study ( $n=70$ ) was 43.1 months.

For the analysis of the association of individual $B C A R$ genes with tumor aggressiveness, 518 LNN patients with ER $\alpha$-positive tumors and who did not receive systemic adjuvant therapy were included. Fifty-three percent of the patients had undergone breast conserving lumpectomy and $100 \%$ node dissection. Adjuvant radiotherapy was given to $60 \%$ of the patients. Patients were evaluated every 3 months for the first 2 years, every 6 months for the next 3 years, and once a year thereafter. Distant metastases were recorded for 195 patients. The median followup of patients alive $(n=346)$ was 96.6 months and the median time to metastasis was 32 months. A total of 172 deaths were recorded.

\section{Tissue processing}

Primary tumor tissue processing was done as described previously (Sieuwerts et al. 2005). In summary, 20-60 cryostat sections of $30 \mu \mathrm{m}$, corresponding to $30-100 \mathrm{mg}$, were cut from frozen tissues for RNA isolation. To assess the amount of tumor cells relative to the amount of surrounding stromal cells, $5 \mu \mathrm{m}$ sections were cut for hematoxylin and eosin staining, before, in between, and after cutting the sections for RNA isolation. For this study, only specimen with at least $30 \%$ tumor nuclei, distributed uniformly over at least $70 \%$ of the section area, was included.

\section{Quantitative RT-PCR}

RNA isolation, cDNA synthesis, and quantification of mRNA and quality control checks were done as described in detail before (Sieuwerts et al. 2005). RNA samples without distinct rRNA bands or failing to amplify efficiently with the housekeeper primer sets (see below) were excluded from this study. Real-time quantitative RT-PCR (qRT-PCR) was performed using an ABI Prism 7700 Sequence detection system (Applied Biosystems) and a Stratagene Mx3000P QPCR System (Agilent Technologies, Waldbronn, Germany). The prominent novel $B C A R$ genes were selected for the development of primer sets designed to 
detect the most abundant splice variants, quality controls, and pilot analyses in a small group of tumor specimens. Specific gene primer sets not meeting the stringent quality criteria (i.e. detection of genomic DNA or poor amplification efficiency) were excluded (Sieuwerts et al. 2005). The primer sets were used in combination with SYBR green PCR Master Mix (Applied Biosystems) and are described in Supplementary Table S1, see section on supplementary data given at the end of this article. Some gene quantifications were performed using inventoried TaqMan Gene Expression Assays from Applied Biosystems in combination with TaqMan Universal PCR Master Mix (Applied Biosystems) and in accordance with the protocol recommended by the manufacturer (Supplementary Table S1). ESR1 and $P G R$ mRNA transcripts were measured as described before (Sieuwerts et al. 2005, 2007). To enable comparison of the mRNA levels in different samples, values were normalized using the average expression levels of a set of housekeeping genes containing $H M B S$, $H P R T 1$, and B2M. Levels of the target genes expressed relative to this housekeeping set were quantified as follows: mRNA target $=2^{\left.\text {(mean } C_{t} \text { housekeeping-mean } C_{t} \text { target }\right)}$ (Sieuwerts et al. 2005). $C_{\mathrm{t}}$ is defined as the detection threshold cycle number.

\section{Statistical analyses}

Statistical computations were done with the use of STATA statistical package, release 10.0 (STATA Corp., College Station, TX, USA). Differences in mRNA levels were assessed with the Mann-Whitney $U$ test or Kruskal-Wallis test, including a Wilcoxontype test for trend, when appropriate. In these tests, patient and tumor characteristics were used as grouping variables. The strengths of the associations between continuous variables were tested with the
Spearman rank correlation $\left(r_{\mathrm{s}}\right)$. To reduce the skewness, variables were $\log$ transformed. All transformed data were normally distributed and analyzed as continuous variables or in quartiles. The Cox proportional hazard model was used to calculate the hazard ratio (HR) and $95 \%$ confidence interval (CI) in the analyses of distant metastasis-free survival (MFS), overall survival (OS), and progression-free survival (PFS). The proportional hazards assumptions were not violated as verified by using Schoenfeld residuals. MFS was defined as the time between removal of the primary tumor and the first detection of a distant metastasis, revealed after symptoms reported by the patients, occurrence of clinical signs, or at regular followup. Death from any cause was considered an event for OS. For all advanced patients treated with tamoxifen, PFS was defined as the time elapsed between initiation of tamoxifen and the first detection of progression of the disease. Logistic regression analysis was used to examine the relationship of mRNA levels with clinical benefit of tamoxifen therapy and for the calculation of the odds ratio (OR) and its $95 \%$ CI. A two-sided $P$ value of $<0.05$ was considered statistically significant.

\section{Results}

\section{Functional screen identifies novel BCAR genes}

We have previously reported the use of a rapid functional screen based on retrovirus-mediated transduction of expression cDNA libraries for the discovery of BCAR genes causing anti-estrogen-resistant cell proliferation (Meijer et al. 2006). These genes were identified following introduction of human placenta, brain, or mouse embryo cDNA libraries into ZR-75-1 cells and selection with 4-hydroxytamoxifen (OH-TAM, summarized in Tables 1 and 2).

Table 1 Functional screens for anti-estrogen-resistant cell proliferation

\begin{tabular}{|c|c|c|c|c|}
\hline Cell line & cDNA library & Anti-estrogen & $\begin{array}{l}\text { Number of target } \\
\text { cells (million) }\end{array}$ & $\begin{array}{l}\text { Number of cell clones } \\
\text { analyzed (number of different } \\
\text { genes identified) }\end{array}$ \\
\hline$M C F-7^{a}$ & Brain & ICI 182780 & 18 (agar) & $3(0)$ \\
\hline $\mathrm{MCF}-7^{\mathrm{a}}$ & Brain/HELA & ICI 182780 & 50 & $5(3)$ \\
\hline ZR-75-1 & Brain & ICI 182780 & 50 & $23(9)$ \\
\hline ZR-75-1 & Brain $^{\mathrm{b}}$ & $\mathrm{OH}-\mathrm{TAM}$ & 30 & $45(31)$ \\
\hline ZR-75-1 & Brain/HELA & OH-TAM & 18 (agar) & 29 (19) \\
\hline ZR-75-1 & Brain & Raloxifene & 5 & $3(2)$ \\
\hline ZR-75-1 & HELA & ICI 182780 & 45 & $54(44)$ \\
\hline ZR-75-1 & Mouse embryo ${ }^{b}$ & OH-TAM & 30 & $30(11)$ \\
\hline ZR-75-1 & Placenta ${ }^{b}$ & OH-TAM & 12 & $80(31)$ \\
\hline
\end{tabular}

${ }^{a}$ Approximately, $25 \%$ of the proliferating colonies survived transfer to microtiter plates and could be analyzed.

${ }^{\mathrm{b}}$ Details previously published (Meijer et al. 2006). 
Table 2 Representation of BCAR genes in anti-estrogen-resistant cell clones derived following transduction of ZR-75-1 cells with different cDNA libraries ${ }^{a}$

\begin{tabular}{|c|c|c|c|c|}
\hline Selection & Brain & HELA & Placenta & Mouse embryo \\
\hline $\mathrm{OH}-\mathrm{TAM}^{\mathrm{b}}$ & $\begin{array}{l}\text { FGF17 (12/45) } \\
\text { NRG1 }(8 / 45)\end{array}$ & & $\begin{array}{l}\text { BCAR4 }(52 / 80) \\
\text { PDGFRB }(12 / 80) \\
\text { EGFR }(4 / 80) \\
\text { CSF1R }(2 / 80)\end{array}$ & $\begin{array}{l}\text { Pdgfrb }(17 / 30) \\
\text { Pdgfra }(7 / 30) \\
\text { Nrg1 }(4 / 30)\end{array}$ \\
\hline $\mathrm{OH}-\mathrm{TAM} / \mathrm{agar}$ & $\begin{array}{l}N R G 1(3 / 18) \\
F B X L 10(3 / 18)^{\mathrm{d}} \\
R A D 21(2 / 18)\end{array}$ & $\operatorname{HRAS}(6 / 11)$ & & \\
\hline ICI 182780 & $\begin{array}{l}\text { NRG1 }(15 / 23) \\
\text { FGF17 (3/23) }\end{array}$ & $\begin{array}{l}\text { HRAS }(19 / 54) \\
\text { RAF1 }(4 / 54)^{\mathrm{e}} \\
\text { RAD21, ABCB1, } \\
\text { RPL18A, EIF1, } \\
\text { EEF1A1 (2/54) }\end{array}$ & & \\
\hline Raloxifene & $N R G 1(3 / 3)$ & & & \\
\hline
\end{tabular}

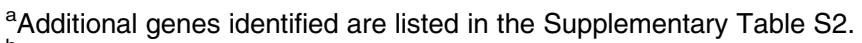

${ }^{b}$ Details previously published (Meijer et al. 2006).

${ }^{\mathrm{C}}$ Number of cell clones containing the gene/total number of cell clones.

dAll cDNA fragments lacking the $5^{\prime}$-terminal part coding for the JmjC domain.

${ }^{\text {e}}$ All cDNA fragments lacking the $5^{\prime}$-terminal part coding for the RAS-binding domain.

We extended these experiments by including a HELA cell line-derived cDNA library, another target cell line, and other culturing conditions including additional anti-estrogen agents. Based on the success of this screening protocol in ZR-75-1 cells (Meijer et al. 2006), infection experiments were carried out using the renown MCF-7 cells as well. In pilot experiments using MCF-7 as a target and ICI 182780 as anti-estrogen (Van Agthoven et al. 1998), only a few resistant cell clones were recovered (Table 1). The majority of these clones lacked an integrated retrovirus, indicating that spontaneous development of resistant colonies occurred at relatively high frequency in MCF-7 cells exposed to ICI 182780 . As a consequence, no further functional screens were performed using the MCF-7 cells.

In the experiments using the ZR-75-1 cell line as a target, all cell clones recovered from the different cultures were found to contain an integrated retrovirus, in agreement with the documented selectivity of this model (Dorssers et al. 1993, Van Agthoven et al. $2009 \mathrm{~b}$ ). From a total of 264 cell clones isolated from these selective cultures, 132 different inserted genes were identified (Table 1 and Supplementary Table S2, see section on supplementary data given at the end of this article). We previously defined a set of criteria for the identification of a $B C A R$ gene causing the resistant phenotype. In brief, a specific gene has to represent the only detectable PCR product in at least one resistant cell clone and should be recovered from at least two cell clones arisen in independent infection events (Meijer et al. 2006). This is to ascertain that abundantly expressed genes, which are recovered from cell clones as passengers and are not responsible for the resistance, are not designated as $B C A R$ genes. These criteria also preclude the possibility that insertion of a cDNAcontaining virus leading to an insertion mutagenesis event, which may occur at a frequency of $\sim 1$ per 10 million infected cells (Van Agthoven et al. 2009b), is mistaken for a BCAR gene. Based on these criteria, our studies identified a total of $15 B C A R$ genes (ABCB1, BCAR4, CSFR1, EEF1A1, EGFR, EIF1, FBXL10, FGF17, HRAS, NRG1, PDGFRA, $P D G F R B, R A D 21, R A F 1$, and RPL18A) individually responsible for anti-estrogen-resistant cell proliferation (Table 2). In most cases, a complete coding sequence lacking mutations was recovered for the respective genes, only the genes $R A F 1$ and FBXL10 were consistently recovered as truncated cDNA fragments from the resistant cell clones (Table 2). In addition to these 15 BCAR genes, another 48 genes (Supplementary Table S2) did not meet these stringent criteria and are considered candidate $B C A R$ genes, which require further studies to confirm their causative role in anti-estrogen-resistant cell proliferation. Already, one of these candidate genes (BCARl) was previously identified by insertional mutagenesis and shown to cause tamoxifen resistance (Brinkman et al. 2000, Van der Flier et al. 2000).

\section{Recovery of individual $B C A R$ genes depends on the biological selection}

Initial experiments were performed using OH-TAM for selection of resistant colonies yielding different 
$B C A R$ genes (Table 2). Further screens were carried out in which anti-estrogens other than OH-TAM were used. While the FGF17 and NRG1 genes predominated in the OH-TAM selection of cells transduced with the brain cDNA library, the NRG1 gene was more often recovered from cell clones selected with ICI 182780 or raloxifene (Table 2). Cell clones transduced with the brain cDNA library were also selected for growth in semi-solid agar medium supplemented with OH-TAM. In contrast to the fluid culture, the FGF17 gene was recovered only once in these semi-solid cultures. In addition to three clones containing $N R G 1$, two novel $B C A R$ genes were identified ( $R A D 21$ and $F B X L 10$ ). In experiments using the HELA cDNA library, HRAS predominated both in cell clones obtained from the selection using ICI 182780 and semi-solid cultures. All together, these results show that by using various cDNA libraries, culture conditions, and anti-estrogens, different $B C A R$ genes can be elucidated.

\section{Overexpression of HRAS, RAF1, and both PDGFRs induces anti-estrogen-resistant growth}

The HRAS gene was recovered from multiple cell clones following transduction of the HELA cDNA library (Table 2) and sequence analysis confirmed the absence of mutations in the integrated cDNAs. For further study, an expression construct was generated in the LZRS-IRES-Neo expression vector. ZR-75-1 cells transfected with the $H R A S$-expression construct showed efficient cell proliferation in the presence of OH-TAM, ICI 182 780, as well as raloxifene (Fig. 1A). Empty vector control cells failed to proliferate under these conditions. We have also transduced expression constructs containing the truncated form of RAF1, lacking the $\mathrm{NH}_{2}$-terminal RAS-binding site, and the complete coding regions from both $P D G F R$ genes into ZR-75-1 cells. As shown in Fig. 1B, expression constructs of RAF1, PDGFRA, and PDGFRB induced cell proliferation in the presence of the anti-estrogen $\mathrm{OH}-\mathrm{TAM}$, while vector control cells were fully growth inhibited. We also observed proliferation for these transduced cells in the presence of raloxifene and ICI 182780 (data not shown). These results support the role of the HRAS, RAF1, PGDFRA, and $P D G F R B$ genes in estrogen-independent and antiestrogen-resistant proliferation of ZR-75-1 cells.

\section{Evaluation of clinical relevance of novel $B C A R$ genes}

Specimens of patients with $E R \alpha$-positive disease were included for the quantification of $B C A R$ mRNAs. In total, 289 tumors were analyzed from patients who received
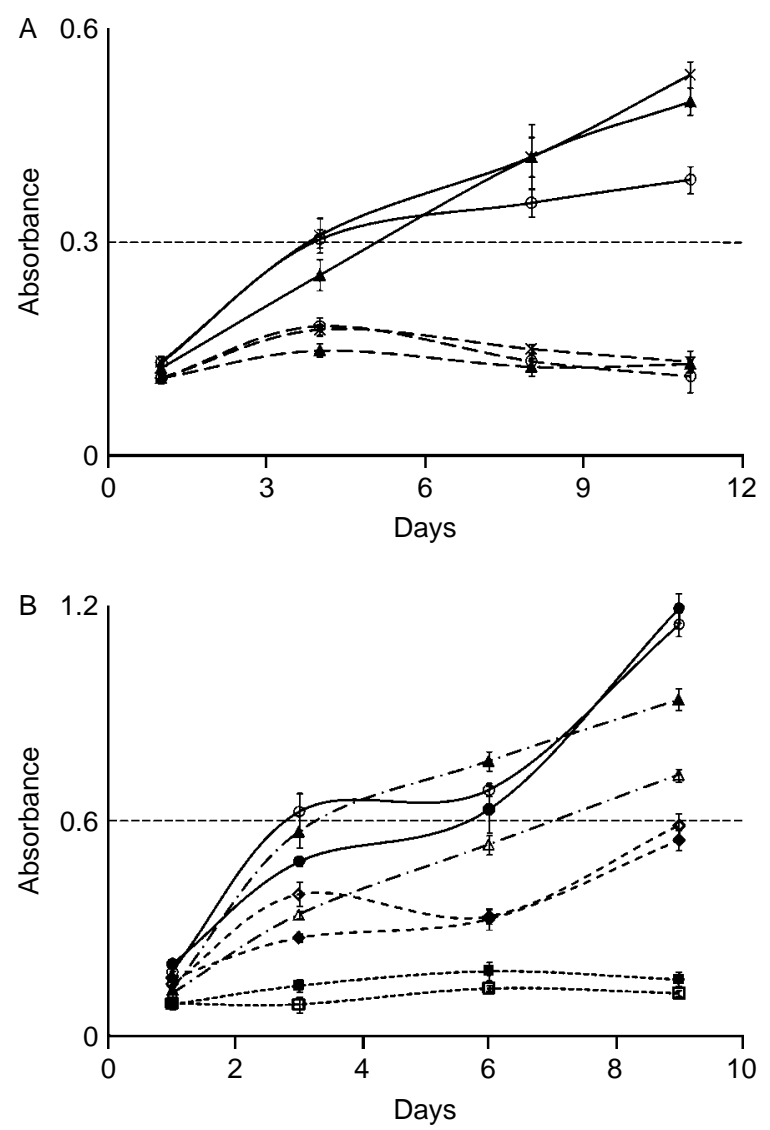

Figure 1 Anti-estrogen resistance of ZR-75-1 cells with forced expression of $B C A R$ genes. (A) Cells transfected with the HRAS expression vector (solid line) or the empty vector (LZRS, dashed line) were seeded at equal density (2500 cells/well) and cultured with OH-TAM $(\bigcirc)$, ICl $182780(\boldsymbol{\Delta})$, or raloxifene $(X)$. Proliferation assays were performed at the indicated time points on eight wells for each condition. Mean absorbance and SD are presented. (B) Independent cell pools transduced with expression vectors containing cDNAs for PDGFRA $(\diamond, \diamond)$, $\operatorname{PDGFRB}(\bigcirc, \mathbf{O}), \operatorname{RAF1}(\boldsymbol{\Lambda}, \triangle)$, or empty vectors $(\boldsymbol{\square}, \square)$ were cultured with $\mathrm{OH}-\mathrm{TAM}$ and measured at the indicated time points as described above.

tamoxifen monotherapy as first-line treatment for advanced disease. In addition, tumor specimens of 518 LNN patients who had not received adjuvant systemic therapy were also available for the study of genes of interest. The mRNA levels of the novel BCAR genes EIF1, FBXL10, HRAS, NRG1, PDGFRA and PDGFRB, RAD21, and $R A F 1$ were determined with quantitative RT-PCR and normalized to a set of three housekeeping genes.

Spearman's rank correlation analyses revealed moderate to strong associations $\left(r_{\mathrm{s}}>0.40 ; P<0.0001\right)$ in mRNA levels between EIF1 and RAD21, between $P D G F R A$ and $P D G F R B$ and NRG1, and between $R A F 1$ and $F B X L 10$ in these primary ER-positive tumors (Supplementary Table S3, see section on supplementary data given at the end of this article). 
Associations of these biological factors with clinicopathological factors showed that reduced PDGFRA and $N R G 1 \mathrm{mRNA}$ levels were associated with older age and post-menopausal status, and that low RAF1 mRNA levels were associated with poor grade (Supplementary Table S4, see section on supplementary data given at the end of this article).

\section{Association of BCAR genes with tamoxifen resistance}

For the evaluation of clinical benefit of first-line tamoxifen treatment, logistic regression analysis was performed on the continuous transformed mRNA levels or following division into four equal parts. Analysis as continuous variables showed high EIFI mRNA levels to be associated with clinical benefit $(\mathrm{OR}=2.59, P=0.0007$, Table 3$)$. Similar results were obtained by analyzing the mRNA levels by quartiles showing the worst outcome for those patients with primary tumors categorized into the lowest quartile of EIF1 mRNA expression (Table 3). To evaluate the independent association of EIF1 mRNA expression with clinical benefit, the traditional predictive factors (age, menopausal status, disease-free interval, dominant site of relapse, and ESRI and PGR mRNA levels)

Table 3 Progression-free survival (PFS) and clinical benefit of 289 patients with advanced estrogen receptor-positive disease following first-line treatment with tamoxifen

\begin{tabular}{|c|c|c|c|c|c|c|c|c|c|c|c|c|c|c|c|c|}
\hline & \multicolumn{8}{|c|}{ PFS } & \multicolumn{8}{|c|}{ Clinical benefit } \\
\hline & \multicolumn{4}{|c|}{ Univariate } & \multicolumn{4}{|c|}{ Multivariate } & \multicolumn{4}{|c|}{ Univariate } & \multicolumn{4}{|c|}{ Multivariate } \\
\hline & HR & \multicolumn{2}{|c|}{$95 \% \mathrm{Cl}$} & $P$ & HR & \multicolumn{2}{|c|}{$95 \% \mathrm{Cl}$} & $P$ & OR & \multicolumn{2}{|c|}{$95 \% \mathrm{Cl}$} & $P$ & OR & \multicolumn{2}{|c|}{$95 \% \mathrm{Cl}$} & $P$ \\
\hline $\begin{array}{l}\text { Age at the start of } \\
\text { therapy (years) }\end{array}$ & & & & 0.0502 & & & & NS & & & & NS & & & & NS \\
\hline$\leq 40$ & 1 & & & & 1 & & & & 1 & & & & 1 & & & \\
\hline $41-55$ & 0.77 & 0.46 & 1.29 & & 0.67 & 0.39 & 1.15 & & 0.83 & 0.29 & 2.37 & & 0.71 & 0.23 & 2.22 & \\
\hline $56-70$ & 0.65 & 0.39 & 1.10 & & 0.52 & 0.27 & 0.99 & & 1.29 & 0.45 & 3.66 & & 0.67 & 0.17 & 2.64 & \\
\hline$>70$ & 0.53 & 0.31 & 0.91 & & 0.44 & 0.22 & 0.86 & & 1.43 & 0.48 & 4.22 & & 0.80 & 0.20 & 3.24 & \\
\hline $\begin{array}{r}\text { Menopausal status at } \\
\text { the start of therapy }\end{array}$ & & & & NS & & & & NS & & & & 0.0544 & & & & NS \\
\hline Pre & 1 & & & & 1 & & & & 1 & & & & & & & \\
\hline Post & 0.85 & 0.64 & 1.12 & & 1.30 & 0.86 & 1.97 & & 1.70 & 0.99 & 2.90 & & 1.48 & 0.63 & 3.52 & \\
\hline $\begin{array}{l}\text { Disease-free interval } \\
\quad \text { (years) }\end{array}$ & & & & 0.0006 & & & & 0.0004 & & & & $<0.0001$ & & & & $<0.0001$ \\
\hline$\leq 1$ & 1 & & & & 1 & & & & 1 & & & & 1 & & & \\
\hline $1-3$ & 0.67 & 0.50 & 0.90 & & 0.66 & 0.49 & 0.89 & & 3.29 & 1.81 & 5.97 & & 3.41 & 1.83 & 6.36 & \\
\hline$>3$ & 0.52 & 0.38 & 0.72 & & 0.50 & 0.36 & 0.70 & & 3.85 & 1.99 & 7.43 & & 4.04 & 2.02 & 8.11 & \\
\hline Dominant site of relapse & & & & NS & & & & NS & & & & NS & & & & NS \\
\hline Local regional & 1 & & & & 1 & & & & 1 & & & & 1 & & & \\
\hline Bone & 1.25 & 0.84 & 1.85 & & 1.15 & 0.76 & 1.75 & & 0.59 & 0.26 & 1.33 & & 0.57 & 0.24 & 1.37 & \\
\hline Viscera & 1.15 & 0.76 & 1.73 & & 1.26 & 0.82 & 1.94 & & 0.79 & 0.34 & 1.83 & & 0.64 & 0.26 & 1.59 & \\
\hline ESR1 mRNA level & & & & & & & & & & & & & & & & \\
\hline Continuous & 0.90 & 0.85 & 0.95 & 0.0002 & 0.91 & 0.85 & 0.97 & 0.0004 & 1.21 & 1.08 & 1.35 & 0.0008 & 1.21 & 1.06 & 1.38 & 0.0053 \\
\hline PGR mRNA level & & & & & & & & & & & & & & & & \\
\hline Continuous & 0.90 & 0.84 & 0.97 & 0.0049 & 0.92 & 0.85 & 0.99 & 0.0290 & 1.09 & 0.94 & 1.26 & NS & 1.02 & 0.86 & 1.20 & NS \\
\hline Factors analyzed & & & & & \multicolumn{4}{|c|}{$\begin{array}{l}\text { Additions to the base } \\
\text { model }^{\mathrm{a}}\end{array}$} & & & & & \multicolumn{4}{|c|}{$\begin{array}{l}\text { Additions to the base } \\
\text { model }^{\mathrm{a}}\end{array}$} \\
\hline$E I F 1(N=226)$ & & & & & & & & & & & & & & & & \\
\hline Continuous & 0.70 & 0.53 & 0.93 & 0.0132 & 0.80 & 0.60 & 1.06 & NS & 2.59 & 1.46 & 4.61 & 0.0007 & 2.61 & 1.35 & 5.05 & 0.0033 \\
\hline In quartiles ${ }^{\mathrm{b}}$ & & & & 0.0593 & & & & NS & & & & 0.0108 & & & & 0.0285 \\
\hline Q2 versus Q1 & 0.63 & 0.43 & 0.93 & & 0.62 & 0.42 & 0.93 & & 2.28 & 1.08 & 4.85 & & 2.13 & 0.93 & 4.89 & \\
\hline Q3 versus Q1 & 0.66 & 0.45 & 0.97 & & 0.65 & 0.44 & 0.97 & & 2.53 & 1.19 & 5.39 & & 2.73 & 1.19 & 6.29 & \\
\hline Q4 versus Q1 & 0.62 & 0.42 & 0.91 & & 0.72 & 0.48 & 1.07 & & 3.39 & 1.56 & 7.38 & & 3.37 & 1.40 & 8.12 & \\
\hline High versus low ${ }^{c}$ & 0.64 & 0.46 & 0.87 & 0.0068 & 0.66 & 0.48 & 0.92 & 0.0160 & 2.69 & 1.45 & 4.97 & 0.0015 & 2.66 & 1.34 & 5.28 & 0.0047 \\
\hline \multicolumn{17}{|l|}{ PDGFRA $(N=283)$} \\
\hline Continuous & 1.10 & 0.95 & 1.28 & NS & 1.00 & 0.86 & 1.17 & NS & 0.82 & 0.61 & 1.11 & NS & 0.97 & 0.69 & 1.35 & NS \\
\hline In quartiles ${ }^{b}$ & & & & 0.0718 & & & & 0.0232 & & & & 0.0108 & & & & 0.0017 \\
\hline Q2 versus Q1 & 1.00 & 0.71 & 1.41 & & 1.06 & 0.74 & 1.52 & & 0.76 & 0.38 & 1.53 & & 0.76 & 0.35 & 1.63 & \\
\hline Q3 versus Q1 & 1.50 & 1.07 & 2.10 & & 1.58 & 1.11 & 2.24 & & 0.35 & 0.18 & 0.70 & & 0.34 & 0.16 & 0.72 & \\
\hline Q4 versus Q1 & 1.19 & 0.85 & 1.67 & & 0.93 & 0.64 & 1.33 & & 0.88 & 0.44 & 1.79 & & 1.40 & 0.64 & 3.10 & \\
\hline
\end{tabular}

$\mathrm{HR}$, hazard ratio; OR, odds ratio; $\mathrm{Cl}$, confidence interval; $\mathrm{Q}$, quartile; $\mathrm{NS}=P>0.1000$.

${ }^{a}$ Factors were separately introduced to the base multivariate model that included the factors age, menopausal status, disease-free interval, dominant site of relapse, and ESR1 and PGR mRNA levels.

${ }^{\mathrm{b}}$ For the analysis in quartiles, HR or OR was set at 1.00 for Q1.

'Stratified into high (Q2-Q4) versus low (Q1). 
(Sieuwerts et al. 2007) were included in the analysis. In univariate and multivariate analyses, disease-free interval and ESRI mRNA levels were significantly associated with clinical benefit. In a multivariate analysis including all the traditional predictive factors, EIF1 was an independent factor when analyzed as continuous variable or in quarters (Table 3). When combining the three highest quartiles in an exploratory analysis, high levels of EIF1 mRNA were associated with favorable outcome. While none of the other genes were significantly related when analyzed as continuous variable (Supplementary Table S5, see section on supplementary data given at the end of this article), categorized PDGFRA mRNA levels showed a significant association in univariate and multivariate analyses of clinical benefit (Table 3). Patients with primary tumors having mRNA levels in the third quartile (i.e. intermediate levels) showed the worst response on tamoxifen. Inclusion of adjuvant chemotherapy as an additional variable did not significantly change the estimates of the individual genes.

Association with PFS after the start of first-line treatment with tamoxifen was assessed with Cox regression analyses. When analyzed as continuous variable, low EIF1 mRNA levels were associated with an early progression $(\mathrm{HR}=0.70, P=0.013$, Table 3 ). Similarly, patients stratified into four equal groups according to increasing mRNA levels showed a longer PFS (Table 3 and Supplementary Figure S1, see section on supplementary data given at the end of this article). An exploratory analysis revealed that patients with primary tumors containing the lowest quarter of EIF 1 mRNA showed a median time to progression of 5.2 months, while the remaining patients with higher levels showed a median time to progression of 10 months after the start of the treatment (Fig. 2A). When combined with the traditional prognostic factors in a multivariate analysis, continuous and categorized EIF1 mRNA levels were significantly associated with PFS (Table 3). The mRNA levels of the other genes did not show statistically significant associations with PFS (Supplementary Table S5). In line with the findings for clinical benefit, categorized mRNA levels of PDGFRA revealed a nonlinear relationship with the largest risk for patients with PDGFRA mRNA levels in the third quartile. The Kaplan-Meier plot showed that half of these patients progressed within 5.6 months, while the remaining groups showed delayed progression (Fig. 2B). The observed associations of PDGFRA and EIFI with PFS were independent of ER levels.
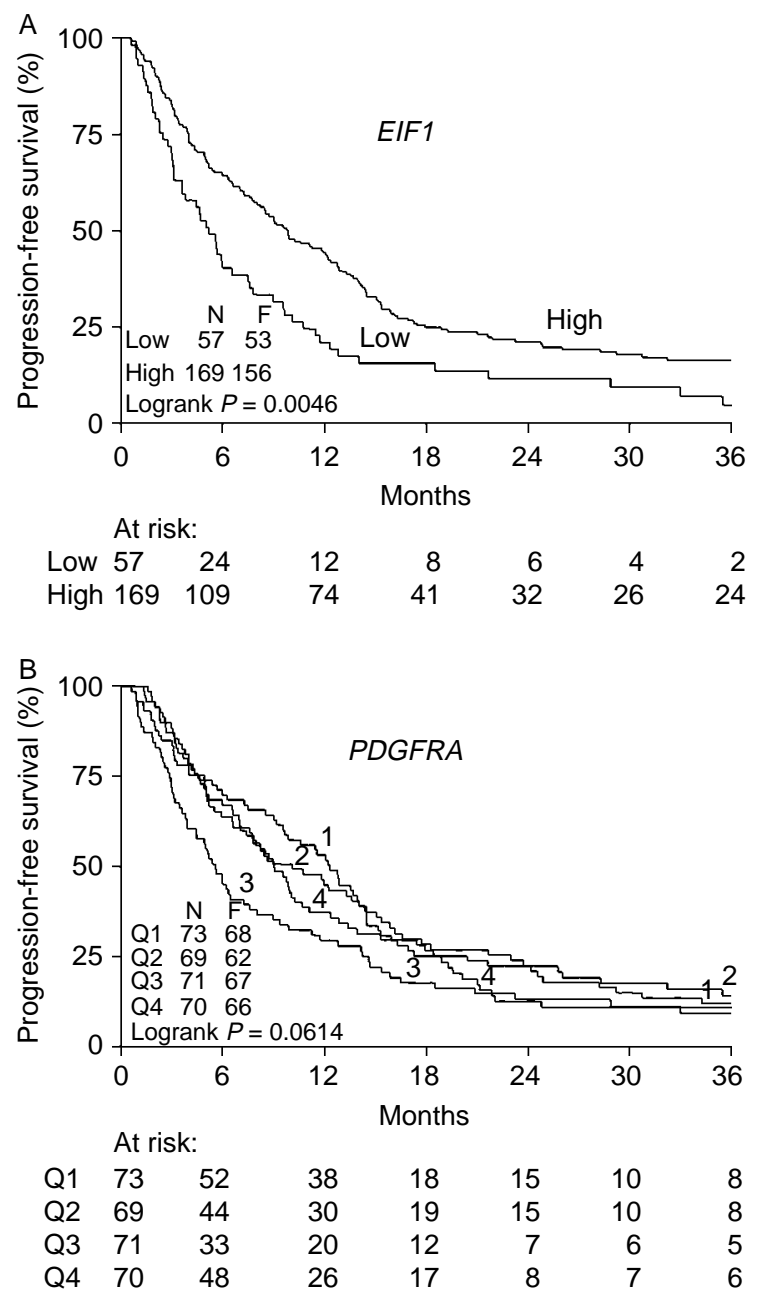

Figure 2 Progression-free survival of ER-positive breast cancer patients with recurrent disease treated with first-line tamoxifen monotherapy. Kaplan-Meier curves for PFS for subgroups of patients as a function of the EIF1 (panel A) or PDGFRA (panel B) mRNA levels of the primary tumors. Patients were divided in groups having primary tumors with high (above the first quarter) or low EIF1 mRNA levels, or in four groups with low, moderate, intermediate, and high PDGFRA mRNA levels. Patients at risk at 24-month intervals are indicated. $N$, number of patients; $F$, number of patients showing progression.

\section{Association of BCAR genes with tumor aggressiveness}

We also determined whether PDGFRA and PDGFRB, $H R A S$, and RAF1 mRNA levels were associated with MFS and OS. For this analysis, we included 518 LNN patients with ER $\alpha$-positive, primary tumors who had not received any adjuvant systemic treatment and thus reflect the natural course of the disease. Uni- and multivariate analyses showed that PDGFRA mRNA levels, analyzed as continuous or categorized variable, were significantly associated with MFS and OS, and 
Table 4 Metastasis-free survival (MFS) and overall survival (OS) of 518 lymph node-negative patients with estrogen receptorpositive breast tumors

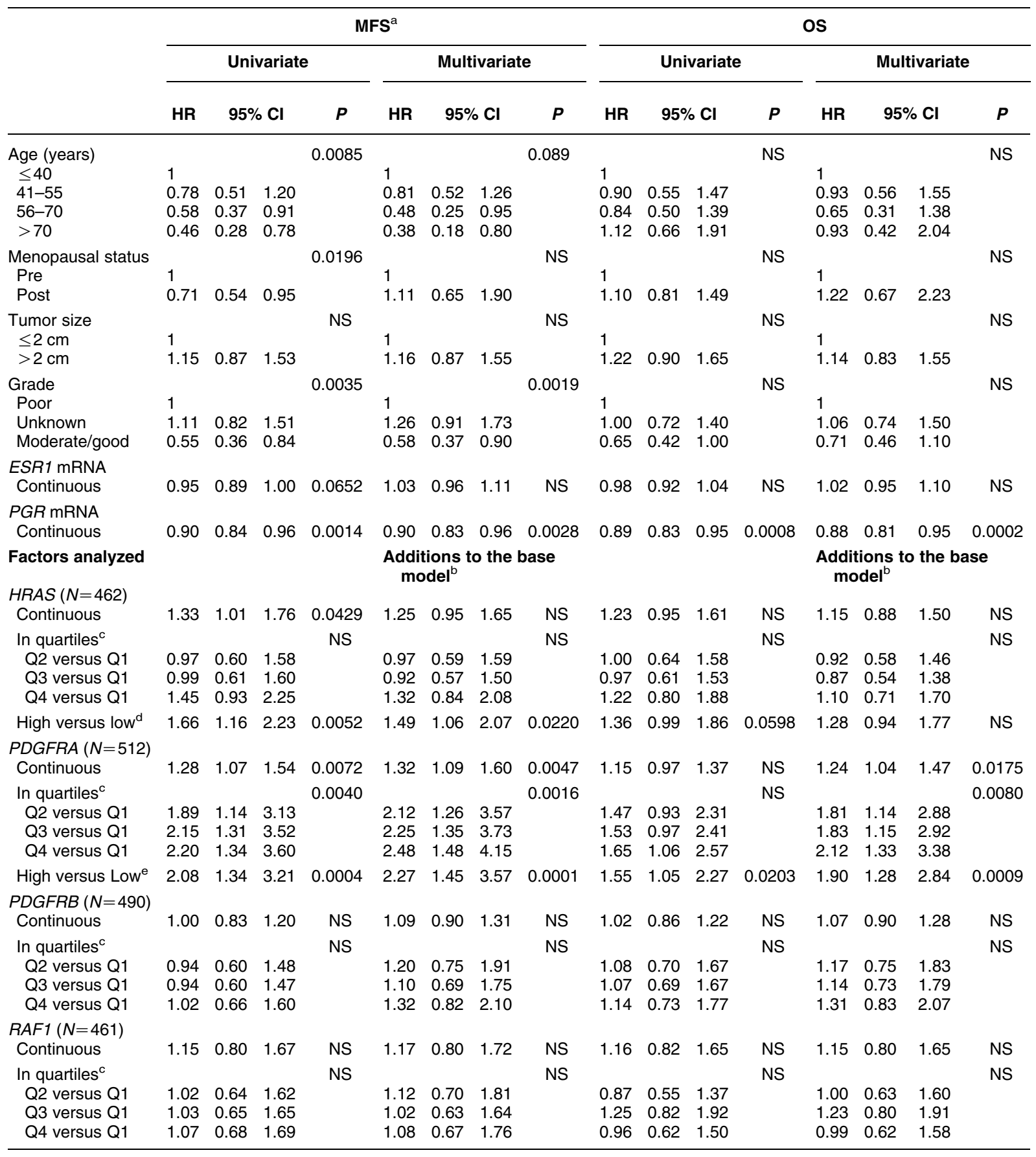

$\mathrm{HR}$, hazard ratio; $\mathrm{Cl}$, confidence interval; $\mathrm{Q}$, quartile; $\mathrm{NS}=P>0.1000$.

${ }^{a}$ MFS was restricted to 60 months to avoid violation of the proportional hazards assumption.

${ }^{b}$ Factors were separately introduced to the base multivariate model that included the factors age, menopausal status, tumor size, grade, and ESR1 and PGR mRNA levels.

${ }^{\circ}$ For the analysis in quartiles, HR was set at 1.00 for Q1.

dStratified into high (top 33\%) and low.

e Stratified into high (top 75\%) and low. 
independent of the traditional prognostic variables (age, menopausal status, tumor size, grade, and ESRI and PGR mRNA levels; Table 4). The Kaplan-Meier analysis showed that patients with tumors containing the lowest levels (quartile 1) of PDGFRA mRNA had the best outcome (Supplementary Figure S2, see section on supplementary data given at the end of this article). When combining the patients with the higher levels of PDGFRA mRNA, their outcome was significantly worse compared with the group with low levels (Fig. 3A and Table 4). PDGFRB and RAF1 mRNA levels were not associated with MFS or OS (Table 4). HRAS, analyzed as a continuous variable in univariate analysis, was significantly associated with MFS in ER-positive tumors (Table 4). The analysis in
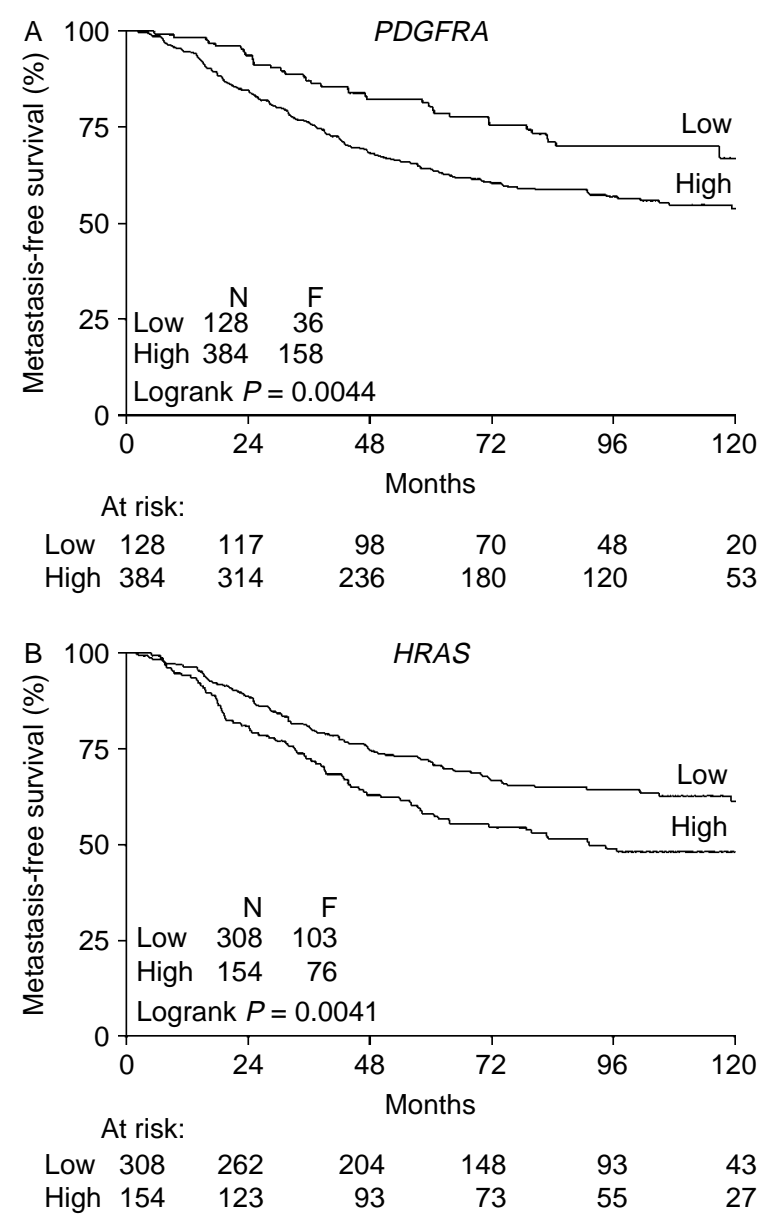

Figure 3 Metastasis-free survival of lymph node-negative patients with ER-positive breast cancer. Kaplan-Meier curves for MFS for subgroups of patients as a function of the PDGFRA (panel A) or HRAS (panel B) mRNA levels of the primary tumors. Patients were divided in two groups having primary tumors with high (PDGFRA top $75 \%$, HRAS top 33\%) or low mRNA levels. Patients at risk at 24-month intervals are indicated. $N$, number of patients; $F$, number of patients with distant recurrences. quartiles revealed a nonsignificant shorter MFS for patients with tumors containing the highest levels of HRAS mRNA (Supplementary Figure S3, see section on supplementary data given at the end of this article). An exploratory analysis, which compared patients with tumors having the highest levels of HRAS mRNA against the other patients, showed a worse prognosis for the group with the highest mRNA levels (Table 4 and Fig. 3B).

\section{Discussion}

Functional genetic screens are a powerful tool to identify specific genes contributing to a particular biological process. In our present study on the identification of genes underlying resistance to antiestrogen compounds in breast cancer, we applied retroviral transduction of cDNA expression libraries, an effective and rapid technique (Brummelkamp \& Bernards 2003, Meijer et al. 2006, Berns et al. 2007, Swanton et al. 2007, Whitehurst et al. 2007). We observed that the nature of the identified genes is strongly dependent on the tissue source and the quality of the cDNA library (Table 2). While the $B C A R 4$ gene dominated in the transduction experiments performed with the placenta cDNA library, FGF17 and NRG1 were overrepresented in cell clones derived with the brain library, and HRAS was frequently recovered with the HELA cell library. These results show that use of different cDNA libraries is essential to get a wide representation of players in the studied phenotype. Obviously, it would be very attractive to use an expression library derived from tamoxifen-resistant breast tumors, but the stringent requirement for intact, full-length cDNAs is likely to present a major obstacle.

Our transfection experiments have shown that many $B C A R$ genes provide resistance to tamoxifen as well as pure anti-estrogens (Van Agthoven et al. 2009b). However, in a screen based on colony formation using different culture conditions, the efficiency of individual genes may vary substantially. We observed that NRG1 was more frequently recovered from resistant colonies under selection with pure anti-estrogen $(65 \%)$ than following selection with tamoxifen $(27 \%)$, while the contribution of $F G F 17$ was slightly reduced under the stringent conditions (from 18\% with tamoxifen to $13 \%$ with ICI 182 780). These results suggest that growth signaling through the EGFR family members is more efficient than along the FGFR pathway under the more restrictive conditions. In the colonies obtained in semisolid cultures, both $N R G 1$ and FGF17 were relatively underrepresented and novel $B C A R$ genes appeared 
(FBXL10 and RAD21). The probability of recovery of a particular gene under different selection conditions may depend on the integration position modulating its level of expression and on the consequences of the particular anti-estrogen on the biology of the ZR-75-1 cells. Our observations that the mechanisms underlying resistance against diverse anti-estrogens differ are in line with previous observations in breast cancer cell models (Soulez \& Parker 2001, Faridi et al. 2003, Frasor et al. 2004, Martin et al. 2005, Fan et al. 2006, Kuske et al. 2006, Scafoglio et al. 2006, Shaw et al. 2006, Osipo et al. 2007). Accordingly, patients with breast tumors failing on tamoxifen have been shown to respond to the pure anti-estrogen fulvestrant (Howell et al. 2002, Osborne et al. 2002, Howell 2006), indicating subtle differences in the underlying mechanisms of tumor growth control. High throughput extension of these screens may help to elucidate the mechanistic differences between the diverse anti-estrogen agents used against breast cancer.

Our list of $B C A R$ genes contains several genes (NRG1, FGF17, HRAS, RAFl, and the membrane receptors PDGFRA, PDGFRB, EGFR, and CSFIR), which are well documented with respect to their role in normal and malignant cell growth (Hunter 2000, Gschwind et al. 2004). In addition, $R A S, R A F$, and PDGFRA are frequently mutated in different types of cancer (Bos 1989, Emuss et al. 2005, Zebisch et al. 2006, Brugge et al. 2007). RAD21 is known to play a role in chromosome cohesion during cell cycle, homologous recombination-mediated double strand break repair, and apoptosis. Reduction of RAD21 expression inhibits proliferation and viability of breast cancer cells and increased their sensitivity to DNA-damaging agents (Atienza et al. 2005). The identification of RAD21 in the screen in ZR-75-1 cells suggests that its overexpression may accelerate the cell cycle and prevent anti-estrogen-induced apoptotic events. F-box proteins function as components of SCF-type E3 ubiquitin ligase complexes and may participate in co-repressor complexes (Gearhart et al. 2006). The presence of a histone demethylase activity in FBXL10 was shown to be important for regulation of cell senescence and transcription of rRNAs (Jin et al. 2004, Takeuchi et al. 2006, Frescas et al. 2007, He et al. 2008, Pfau et al. 2008, Yamagishi et al. 2008). In our experiments, truncated versions of FBXL10 gene were recovered lacking the $5^{\prime}$-terminal part encoding the demethylase domain. As a consequence of its overexpression, this variant may overrule the function of the endogenous protein and enhance cell proliferation in anti-estrogen-treated breast cancer cells. How BCAR4 (Meijer et al. 2006) and the genes involved in
mRNA translation (EIF1, EEF1A1, and RPL18A) induce anti-estrogen-resistant cell proliferation remains to be resolved.

The analyses for clinical relevance of several novel $B C A R$ genes, revealed by retroviral transduction of cDNA expression libraries, showed significant associations with tamoxifen resistance for EIFl and $P D G F R A$, and with tumor aggressiveness (i.e. metastatic potential) for $H R A S$ and PDGFRA, although replication in an independent group of patients will be needed to obtain definite proof. EIF1 is a translation initiation factor involved in start codon selection (Fraser \& Doudna 2007). While little was known about EIF1, other components of protein translation have been implicated in malignant processes involving either TP53 or acting downstream of PI3K/AKT/ MTOR by selectively increasing translation of subsets of mRNAs (Armengol et al. 2007, MacInnes et al. 2008, Sonenberg 2008, Zhang et al. 2008, Chakraborty et al. 2009, Lai et al. 2009). Furthermore, EEF1A protein levels were increased in breast tumors with high proteasome activity (Chen \& Madura 2005). Low EIF1 mRNA levels in breast tumors are associated with shorter PFS and poor clinical benefit of tamoxifen treatment, while high levels cause the resistance in the in vitro cell model. Similar observations were made for BCAR3 and TLE3 (Van Agthoven et al. 2009a), indicating that our cell model cannot fully replicate the clinical situation, known to be heterogeneous. Mutations in PDGFRA, yielding constitutive activation of this receptor, drive malignant behavior in gastrointestinal stromal tumors (Heinrich et al. 2003, Hirota et al. 2003). Both PDGFRs have been implicated in the invasive potential of breast tumors (Jechlinger et al. 2006, Paulsson et al. 2009). In breast cancer, our results showed an association of high PDGFRA mRNA levels with rapid recurrence of the disease. Furthermore, advanced breast cancer patients with primary tumors with mRNA levels in the third quartile did worse in terms of clinical benefit and PFS. These results may suggest that patients with ER-positive tumors containing PDGFRA in the third quartile are unlikely to benefit from adjuvant tamoxifen treatment. In contrast to PDGFRA mRNA levels, we did not observe any relationship between breast cancer progression and tamoxifen resistance for PDGFRB. HRAS is rarely mutated in breast cancer (Hollestelle et al. 2007), but high mRNA levels were found to be associated with increased metastatic potential in untreated patients in line with its reported role in progression and invasion (Watson et al. 1991, Gelmann et al. 1992, Moon et al. 2000, Worsham et al. 2006). 
No associations of $R A F 1$ or NRG1 mRNA levels with tamoxifen resistance were observed in our study. Recently, RAF1 has been shown to be a direct target for down-regulation by miR-7 (Webster et al. 2009), and high levels of this miRNA have been linked to poor prognosis of breast cancer patients (Foekens et al. 2008). Furthermore, RAF1 has been suggested to contribute to tamoxifen resistance induced by the loss of CDK10 in MCF-7 cells (Iorns et al. 2008). Although only incomplete versions of RAF1 were recovered from our current screen, it is uncertain whether the loss of the RAS-binding domain is a pre-requisite for anti-estrogen-resistant growth of the breast cancer cells. NRG1 was previously shown to induce tamoxifen-resistant and invasive growth (Atlas et al. 2003), and is expressed at variable levels and amplified in breast tumors (Huang et al. 2004, Prentice et al. 2005, Hutcheson et al. 2007). These published associations suggest that $R A F 1$ or NRG1 mRNA levels are not decisive in clinical tamoxifen resistance and that post-transcriptional regulation may be more important for these $B C A R$ genes. Alternatively, the functional partners of $B C A R$ genes may be rate limiting and exhibit significant associations as previously noted for FGF17/FGFR4 (Meijer et al. 2008).

In conclusion, the recovery frequencies of individual $B C A R$ genes upon selection with various anti-estrogens illustrate the biological differences of these drugs for cellular resistance to growth inhibition. Further largescale transduction experiments may characterize these fundamental differences and provide rationale for the prescription of an appropriate drug to a given patient. Furthermore, the clinical associations of the different $B C A R$ genes identified in our cell model (Van der Flier et al. 2000, Dorssers et al. 2004a,b, Meijer et al. 2008, 2009, Van Agthoven et al. 2009a,c) and their mode of action will provide insights into the mechanisms of tumor aggressiveness and endocrine therapy response, and may help to design improved treatments aiming at prolonged control of the disease.

\section{Supplementary data}

This is linked to the online version of the paper at http://dx. doi.org/10.1677/ERC-09-0062.

\section{Declaration of interest}

The authors declare that there is no conflict of interest that could be perceived as prejudicing the impartiality of the research reported.

\section{Funding}

Parts of this study were supported by grants of the Association for International Cancer Research (04-148), the Erasmus MC (Breedtestrategie), the Dutch Cancer Society, the Susan G Komen Breast Cancer Foundation, and The Netherlands Genomic Initiative (NGI)/Netherlands Organization for Scientific Research (NWO).

\section{Acknowledgements}

We thank Vanja de Weerd, Mieke Timmermans, Els Berns, Maurice Jansen, and Maxime Look for their support. We thank Dr Carl-Hendrik Heldin for providing the cDNA clones for the PDGFRs. For stimulating discussions and suggestions we are indebted to our colleagues at the Josephine Nefkens Institute.

\section{References}

Ali S \& Coombes RC 2002 Endocrine-responsive breast cancer and strategies for combating resistance. Nature Reviews. Cancer 2 101-112.

Armengol G, Rojo F, Castellvi J, Iglesias C, Cuatrecasas M, Pons B, Baselga J \& Ramon y Cajal S 2007 4E-binding protein 1: a key molecular "funnel factor" in human cancer with clinical implications. Cancer Research 67 7551-7555.

Atienza JM, Roth RB, Rosette C, Smylie KJ, Kammerer S, Rehbock J, Ekblom J \& Denissenko MF 2005

Suppression of RAD21 gene expression decreases cell growth and enhances cytotoxicity of etoposide and bleomycin in human breast cancer cells. Molecular Cancer Therapeutics 4 361-368.

Atlas E, Cardillo M, Mehmi I, Zahedkargaran H, Tang C \& Lupu R 2003 Heregulin is sufficient for the promotion of tumorigenicity and metastasis of breast cancer cells in vivo. Molecular Cancer Research 1 165-175.

Berns K, Horlings HM, Hennessy BT, Madiredjo M, Hijmans EM, Beelen K, Linn SC, Gonzalez-Angulo AM, StemkeHale K, Hauptmann M et al. 2007 A functional genetic approach identifies the PI3K pathway as a major determinant of trastuzumab resistance in breast cancer. Cancer Cell 12 395-402.

Bos JL 1989 ras Oncogenes in human cancer: a review. Cancer Research 49 4682-4689.

Brinkman A, Van der Flier S, Kok EM \& Dorssers LCJ 2000 BCAR1, a human homologue of the adapter protein p130Cas and antiestrogen resistance in breast cancer cells. Journal of the National Cancer Institute 92 112-120.

Brugge J, Hung MC \& Mills GB 2007 A new mutational AKTivation in the PI3K pathway. Cancer Cell 12 104-107.

Brummelkamp TR \& Bernards R 2003 New tools for functional mammalian cancer genetics. Nature Reviews. Cancer 3 781-789. 
Chakraborty A, Uechi T, Higa S, Torihara H \& Kenmochi N 2009 Loss of ribosomal protein L11 affects zebrafish embryonic development through a p53-dependent apoptotic response. PLoS ONE 4 e4152.

Chen L \& Madura K 2005 Increased proteasome activity, ubiquitin-conjugating enzymes, and eEF1A translation factor detected in breast cancer tissue. Cancer Research 65 5599-5606.

Clarke R, Liu MC, Bouker KB, Gu Z, Lee RY, Zhu Y, Skaar TC, Gomez B, O'Brien K, Wang Y et al. 2003

Antiestrogen resistance in breast cancer and the role of estrogen receptor signaling. Oncogene 22 7316-7339.

Come SE, Buzdar AU, Ingle JN, Johnston SR, Brodie AM, Coombes RC, Miller WR, Pritchard KI, Winer EP, Zujewski JA et al. 2008 Endocrine and targeted manipulation of breast cancer: summary statement for the Sixth Cambridge Conference. Cancer 112 673-678.

Cuzick J, Forbes JF, Sestak I, Cawthorn S, Hamed H, Holli K, Howell A \& International Breast Cancer Intervention Study II 2007 Long-term results of tamoxifen prophylaxis for breast cancer - 96-month follow-up of the randomized IBIS-I trial. Journal of the National Cancer Institute 99 272-282.

Dorssers LCJ, Van Agthoven T, Dekker A, Van Agthoven TLA \& Kok EM 1993 Induction of antiestrogen resistance in human breast cancer cells by random insertional mutagenesis using defective retroviruses: identification of bcar-1, a common integration site. Molecular Endocrinology 7 870-878.

Dorssers LCJ, Van der Flier S, Brinkman A, Van Agthoven T, Veldscholte J, Berns EMJJ, Klijn JGM, Beex LVAM \& Foekens JA 2001 Tamoxifen resistance in breast cancer: elucidating mechanisms. Drugs 61 1721-1733.

Dorssers LCJ, Grebenchtchikov N, Brinkman A, Look MP, Klijn JGM, Geurts-Moespot A, Span PN, Foekens JA \& Sweep CGJ 2004a Application of a newly developed ELISA for BCAR1 protein for prediction of clinical benefit of tamoxifen therapy in patients with advanced breast cancer. Clinical Chemistry 50 1445-1447.

Dorssers LCJ, Grebenchtchikov N, Brinkman A, Look MP, Van Broekhoven SPJ, De Jong D, Peters HA, Portengen H, Meijer-Van Gelder ME, Klijn JGM et al. 2004b The prognostic value of BCAR1 in patients with primary breast cancer. Clinical Cancer Research 10 6194-6202.

Early Breast Cancer Trialists' Collaborative Group 1998 Tamoxifen for early breast cancer: an overview of the randomised trials. Lancet 351 1451-1467.

Early Breast Cancer Trialists' Collaborative Group 2005 Effects of chemotherapy and hormonal therapy for early breast cancer on recurrence and 15-year survival: an overview of the randomised trials. Lancet $\mathbf{3 6 5}$ 1687-1717.

Emuss V, Garnett M, Mason C \& Marais R 2005 Mutations of C-RAF are rare in human cancer because C-RAF has a low basal kinase activity compared with B-RAF. Cancer Research 65 9719-9726.
EORTC Breast Cancer Cooperative Group 2000 Manual for clinical research and treatment in breast cancer, pp 116-117, Almere, The Netherlands: Excerpta Medical.

Fan M, Yan PS, Hartman-Frey C, Chen L, Paik H, Oyer SL, Salisbury JD, Cheng AS, Li L, Abbosh PH et al. 2006 Diverse gene expression and DNA methylation profiles correlate with differential adaptation of breast cancer cells to the antiestrogens tamoxifen and fulvestrant. Cancer Research 66 11954-11966.

Faridi J, Wang L, Endemann G \& Roth RA 2003 Expression of constitutively active Akt-3 in MCF-7 breast cancer cells reverses the estrogen and tamoxifen responsivity of these cells in vivo. Clinical Cancer Research 9 2933-2939.

Foekens JA, Portengen H, van Putten WL, Peters HA, Krijnen HL, Alexieva-Figusch J \& Klijn JG 1989 Prognostic value of estrogen and progesterone receptors measured by enzyme immunoassays in human breast tumor cytosols. Cancer Research 49 5823-5828.

Foekens JA, Sieuwerts AM, Smid M, Look MP, de Weerd V, Boersma AW, Klijn JG, Wiemer EA \& Martens JW 2008 Four miRNAs associated with aggressiveness of lymph node-negative, estrogen receptor-positive human breast cancer. PNAS 105 13021-13026.

Fraser CS \& Doudna JA 2007 Structural and mechanistic insights into hepatitis $\mathrm{C}$ viral translation initiation. Nature Reviews. Microbiology 5 29-38.

Frasor J, Stossi F, Danes JM, Komm B, Lyttle CR \& Katzenellenbogen BS 2004 Selective estrogen receptor modulators: discrimination of agonistic versus antagonistic activities by gene expression profiling in breast cancer cells. Cancer Research 64 1522-1533.

Frescas D, Guardavaccaro D, Bassermann F, Koyama-Nasu R \& Pagano M 2007 JHDM1B/FBXL10 is a nucleolar protein that represses transcription of ribosomal RNA genes. Nature 450 309-313.

Gearhart MD, Corcoran CM, Wamstad JA \& Bardwell VJ 2006 Polycomb group and SCF ubiquitin ligases are found in a novel BCOR complex that is recruited to BCL6 targets. Molecular and Cellular Biology 26 6880-6889.

Gelmann EP, Thompson EW \& Sommers CL 1992 Invasive and metastatic properties of MCF-7 cells and rasH-transfected MCF-7 cell lines. International Journal of Cancer 50 665-669.

Gschwind A, Fischer OM \& Ullrich A 2004 The discovery of receptor tyrosine kinases: targets for cancer therapy. Nature Reviews. Cancer 4 361-370.

Gutierrez MC, Detre S, Johnston S, Mohsin SK, Shou J, Allred DC, Schiff R, Osborne CK \& Dowsett M 2005 Molecular changes in tamoxifen-resistant breast cancer: relationship between estrogen receptor, HER-2, and p38 mitogen-activated protein kinase. Journal of Clinical Oncology 23 2469-2476.

Hayward JL, Carbone PP, Heuson JC, Kumaoka S, Segaloff A \& Rubens RD 1977 Assessment of response to therapy 
in advanced breast cancer: a project of the Programme on Clinical Oncology of the International Union Against Cancer, Geneva, Switzerland. Cancer 39 1289-1293.

He J, Kallin EM, Tsukada Y \& Zhang Y 2008 The H3K36 demethylase $\mathrm{Jhdm} 1 \mathrm{~b} / \mathrm{Kdm} 2 \mathrm{~b}$ regulates cell proliferation and senescence through p15(Ink4b). Nature Structural \& Molecular Biology 15 1169-1175.

Heinrich MC, Corless CL, Duensing A, McGreevey L, Chen CJ, Joseph N, Singer S, Griffith DJ, Haley A, Town A et al. 2003 PDGFRA activating mutations in gastrointestinal stromal tumors. Science 299 708-710.

Hirota S, Ohashi A, Nishida T, Isozaki K, Kinoshita K, Shinomura Y \& Kitamura Y 2003 Gain-of-function mutations of platelet-derived growth factor receptor alpha gene in gastrointestinal stromal tumors. Gastroenterology 125 660-667.

Hollestelle A, Elstrodt F, Nagel JH, Kallemeijn WW \& Schutte M 2007 Phosphatidylinositol-3-OH kinase or RAS pathway mutations in human breast cancer cell lines. Molecular Cancer Research 5 195-201.

Howell A 2005 The future of fulvestrant ("Faslodex"). Cancer Treatment Reviews 31 (Suppl 2) S26-S33.

Howell A 2006 Pure oestrogen antagonists for the treatment of advanced breast cancer. Endocrine-Related Cancer 13 689-706.

Howell A, Robertson JF, Quaresma Albano J, Aschermannova A, Mauriac L, Kleeberg UR, Vergote I, Erikstein B, Webster A \& Morris C 2002 Fulvestrant, formerly ICI 182,780 , is as effective as anastrozole in postmenopausal women with advanced breast cancer progressing after prior endocrine treatment. Journal of Clinical Oncology 20 3396-3403.

Howell SJ, Johnston SR \& Howell A 2004 The use of selective estrogen receptor modulators and selective estrogen receptor down-regulators in breast cancer. Best Practice \& Research. Clinical Endocrinology \& Metabolism 18 47-66.

Huang HE, Chin SF, Ginestier C, Bardou VJ, Adelaide J, Iyer NG, Garcia MJ, Pole JC, Callagy GM, Hewitt SM et al. 2004 A recurrent chromosome breakpoint in breast cancer at the NRG1/neuregulin 1/heregulin gene. Cancer Research 64 6840-6844.

Hunter T 2000 Signaling - 2000 and beyond. Cell 100 113-127.

Hurtado A, Holmes KA, Geistlinger TR, Hutcheson IR, Nicholson RI, Brown M, Jiang J, Howat WJ, Ali S \& Carroll JS 2008 Regulation of ERBB2 by oestrogen receptor-PAX2 determines response to tamoxifen. Nature 456 663-666.

Hutcheson IR, Knowlden JM, Hiscox SE, Barrow D, Gee JM, Robertson JF, Ellis IO \& Nicholson RI 2007 Heregulin beta1 drives gefitinib-resistant growth and invasion in tamoxifen-resistant MCF-7 breast cancer cells. Breast Cancer Research 9 R50.

Iorns E, Turner NC, Elliott R, Syed N, Garrone O, Gasco M, Tutt AN, Crook T, Lord CJ \& Ashworth A 2008
Identification of CDK10 as an important determinant of resistance to endocrine therapy for breast cancer. Cancer Cell 13 91-104.

Jaiyesimi IA, Buzdar AU, Decker DA \& Hortobagyi GN 1995 Use of tamoxifen for breast cancer: twenty-eight years later. Journal of Clinical Oncology 13 513-529.

Jechlinger M, Sommer A, Moriggl R, Seither P, Kraut N, Capodiecci P, Donovan M, Cordon-Cardo C, Beug H \& Grunert S 2006 Autocrine PDGFR signaling promotes mammary cancer metastasis. Journal of Clinical Investigation 116 1561-1570.

Jin J, Cardozo T, Lovering RC, Elledge SJ, Pagano M \& Harper JW 2004 Systematic analysis and nomenclature of mammalian F-box proteins. Genes and Development 18 2573-2580.

Johnston SR 2005 Endocrinology and hormone therapy in breast cancer: selective oestrogen receptor modulators and downregulators for breast cancer - have they lost their way? Breast Cancer Research 7 119-130.

Jordan VC 1995 Third annual William L McGuire memorial lecture - studies on the estrogen receptor in breast cancer 20 years as a target for the treatment and prevention of cancer. Breast Cancer Research and Treatment 36 267-285.

Kuske B, Naughton C, Moore K, Macleod KG, Miller WR, Clarke R, Langdon SP \& Cameron DA 2006 Endocrine therapy resistance can be associated with high estrogen receptor alpha (ERalpha) expression and reduced ERalpha phosphorylation in breast cancer models. Endocrine-Related Cancer 13 1121-1133.

Lai K, Amsterdam A, Farrington S, Bronson RT, Hopkins N \& Lees JA 2009 Many ribosomal protein mutations are associated with growth impairment and tumor predisposition in zebrafish. Developmental Dynamics 238 76-85.

Lerner LJ \& Jordan VC 1990 Development of antiestrogens and their use in breast cancer: eight Cain memorial award lecture. Cancer Research 50 4177-4189.

MacInnes AW, Amsterdam A, Whittaker CA, Hopkins N \& Lees JA 2008 Loss of p53 synthesis in zebrafish tumors with ribosomal protein gene mutations. PNAS $\mathbf{1 0 5}$ 10408-10413.

Martin LA, Pancholi S, Chan CM, Farmer I, Kimberley C, Dowsett M \& Johnston SR 2005 The anti-oestrogen ICI 182,780, but not tamoxifen, inhibits the growth of MCF-7 breast cancer cells refractory to long-term oestrogen deprivation through down-regulation of oestrogen receptor and IGF signalling. Endocrine-Related Cancer 12 1017-1036.

McShane LM, Altman DG, Sauerbrei W, Taube SE, Gion M, Clark GM \& Statistics Subcommittee of NCIEWGoCD 2006 REporting recommendations for tumor MARKer prognostic studies (REMARK). Breast Cancer Research and Treatment 100 229-235.

Meijer D, Van Agthoven T, Bosma PT, Nooter K \& Dorssers LCJ 2006 Functional screen for genes responsible for tamoxifen resistance in human breast cancer cells. Molecular Cancer Research 4 379-386. 
Meijer D, Sieuwerts AM, Look MP, Van Agthoven T, Foekens JA \& Dorssers LCJ 2008 Fibroblast growth factor receptor 4 predicts failure on tamoxifen therapy in patients with recurrent breast cancer. Endocrine-Related Cancer 15 101-111.

Meijer D, Jansen MPHM, Look MP, Ruigrok-Ritstier K, Van Staveren IL, Sieuwerts AM, Van Agthoven T, Foekens JA, Dorssers LCJ \& Berns EMJJ 2009 TSC22D1 and PSAP predict clinical outcome of tamoxifen treatment in patients with recurrent breast cancer. Breast Cancer Research and Treatment 113 253-260.

Moon A, Kim MS, Kim TG, Kim SH, Kim HE, Chen YQ \& Kim HR 2000 H-ras, but not N-ras, induces an invasive phenotype in human breast epithelial cells: a role for MMP-2 in the H-ras-induced invasive phenotype. International Journal of Cancer $\mathbf{8 5}$ 176-181.

Nicholson RI, Hutcheson IR, Britton D, Knowlden JM, Jones HE, Harper ME, Hiscox SE, Barrow D \& Gee JM 2005 Growth factor signalling networks in breast cancer and resistance to endocrine agents: new therapeutic strategies. Journal of Steroid Biochemistry and Molecular Biology 93 257-262.

Osborne CK \& Schiff R 2005 Estrogen-receptor biology: continuing progress and therapeutic implications. Journal of Clinical Oncology 23 1616-1622.

Osborne CK, Pippen J, Jones SE, Parker LM, Ellis M, Come S, Gertler SZ, May JT, Burton G, Dimery I et al. 2002 Double-blind, randomized trial comparing the efficacy and tolerability of fulvestrant versus anastrozole in postmenopausal women with advanced breast cancer progressing on prior endocrine therapy: results of a North American trial. Journal of Clinical Oncology 20 3386-3395.

Osipo C, Meeke K, Cheng D, Weichel A, Bertucci A, Liu H \& Jordan VC 2007 Role for HER2/neu and HER3 in fulvestrant-resistant breast cancer. International Journal of Oncology 30 509-520.

Paulsson J, Sjoblom T, Micke P, Ponten F, Landberg G, Heldin CH, Bergh J, Brennan DJ, Jirstrom K \& Ostman A 2009 Prognostic significance of stromal platelet-derived growth factor $\{$ beta\}-receptor expression in human breast cancer. American Journal of Pathology 17 334-341.

Pfau R, Tzatsos A, Kampranis SC, Serebrennikova OB, Bear SE \& Tsichlis PN 2008 Members of a family of JmjC domain-containing oncoproteins immortalize embryonic fibroblasts via a JmjC domain-dependent process. PNAS 105 1907-1912.

Prentice LM, Shadeo A, Lestou VS, Miller MA, deLeeuw RJ, Makretsov N, Turbin D, Brown LA, Macpherson N, Yorida E et al. 2005 NRG1 gene rearrangements in clinical breast cancer: identification of an adjacent novel amplicon associated with poor prognosis. Oncogene $\mathbf{2 4}$ 7281-7289.
Riggins RB, Schrecengost RS, Guerrero MS \& Bouton AH 2007 Pathways to tamoxifen resistance. Cancer Letters 256 1-24.

Scafoglio C, Ambrosino C, Cicatiello L, Altucci L, Ardovino M, Bontempo P, Medici N, Molinari AM, Nebbioso A, Facchiano A et al. 2006 Comparative gene expression profiling reveals partially overlapping but distinct genomic actions of different antiestrogens in human breast cancer cells. Journal of Cellular Biochemistry $\mathbf{9 8}$ 1163-1184.

Shaw LE, Sadler AJ, Pugazhendhi D \& Darbre PD 2006 Changes in oestrogen receptor-alpha and -beta during progression to acquired resistance to tamoxifen and fulvestrant (Faslodex, ICI 182,780) in MCF7 human breast cancer cells. Journal of Steroid Biochemistry and Molecular Biology 99 19-32.

Sieuwerts AM, Meijer-van Gelder ME, Timmermans M, Trapman AM, Garcia RR, Arnold M, Goedheer AJ, Portengen H, Klijn JG \& Foekens JA 2005 How ADAM-9 and ADAM-11 differentially from estrogen receptor predict response to tamoxifen treatment in patients with recurrent breast cancer: a retrospective study. Clinical Cancer Research 11 7311-7321.

Sieuwerts AM, Usher PA, Meijer-van Gelder ME, Timmermans M, Martens JW, Brunner N, Klijn JG, Offenberg H \& Foekens JA 2007 Concentrations of TIMP1 mRNA splice variants and TIMP-1 protein are differentially associated with prognosis in primary breast cancer. Clinical Chemistry 53 1280-1288.

Sonenberg N 2008 eIF4E, the mRNA cap-binding protein: from basic discovery to translational research. Biochemistry and Cell Biology 86 178-183.

Soulez M \& Parker MG 2001 Identification of novel oestrogen receptor target genes in human ZR75-1 breast cancer cells by expression profiling. Journal of Molecular Endocrinology 27 259-274.

Swanton C, Marani M, Pardo O, Warne PH, Kelly G, Sahai E, Elustondo F, Chang J, Temple J, Ahmed AA et al. 2007 Regulators of mitotic arrest and ceramide metabolism are determinants of sensitivity to paclitaxel and other chemotherapeutic drugs. Cancer Cell 11 498-512.

Takeuchi T, Watanabe Y, Takano-Shimizu T \& Kondo S 2006 Roles of jumonji and jumonji family genes in chromatin regulation and development. Developmental Dynamics 235 2449-2459.

Van Agthoven T, Van Agthoven TLA, Portengen H, Foekens JA \& Dorssers LCJ 1992 Ectopic expression of epidermal growth factor receptors induces hormone independence in ZR-75-1 human breast cancer cells. Cancer Research 52 5082-5088.

Van Agthoven T, Van Agthoven TLA, Dekker A, Van der Spek PJ, Vreede L \& Dorssers LCJ 1998 Identification of BCAR3 by a random search for genes involved in antiestrogen resistance of human breast cancer cells. EMBO Journal 17 2799-2808. 
Van Agthoven T, Sieuwerts AM, Meijer-Van Gelder ME, Look MP, Smid M, Veldscholte J, Sleijfer S, Foekens JA \& Dorssers LCJ $2009 a$ Relevance of breast cancer antiestrogen resistance genes in human breast cancer progression and tamoxifen resistance. Journal of Clinical Oncology 27 542-549.

Van Agthoven T, Veldscholte J, Smid M, Van Agthoven TLA, Vreede L, Broertjes M, De Vries I, De Jong D, Sarwari R \& Dorssers LCJ $2009 b$ Functional identification of genes causing estrogen independence of human breast cancer cells. Breast Cancer Research and Treatment 114 23-30.

Van Agthoven T, Sieuwerts AM, Veldscholte J, Meijer-van Gelder ME, Smid M, Brinkman A, den Dekker AT, Leroy IM, van Ijcken WF, Sleijfer S et al. 2009c CITED2 and NCOR2 in anti-oestrogen resistance and progression of breast cancer. British Journal of Cancer [in press].

Van der Flier S, Brinkman A, Look MP, Kok EM, MeijerVan Gelder ME, Klijn JGM, Dorssers LCJ \& Foekens JA 2000 Bcar1/p130Cas protein and primary breast cancer: prognosis and response to tamoxifen treatment. Journal of the National Cancer Institute 92 120-127.

Watson DM, Elton RA, Jack WJ, Dixon JM, Chetty U \& Miller WR 1991 The H-ras oncogene product p21 and prognosis in human breast cancer. Breast Cancer Research and Treatment 17 161-169.

Webster RJ, Giles KM, Price KJ, Zhang PM, Mattick JS \& Leedman PJ 2009 Regulation of epidermal growth factor receptor signaling in human cancer cells by microRNA-7. Journal of Biological Chemistry 284 5731-5741.
Whitehurst AW, Bodemann BO, Cardenas J, Ferguson D, Girard L, Peyton M, Minna JD, Michnoff C, Hao W, Roth MG et al. 2007 Synthetic lethal screen identification of chemosensitizer loci in cancer cells. Nature 446 815-819.

Worsham MJ, Pals G, Schouten JP, Miller F, Tiwari N, van Spaendonk R \& Wolman SR 2006 High-resolution mapping of molecular events associated with immortalization, transformation, and progression to breast cancer in the MCF10 model. Breast Cancer Research and Treatment 96 177-186.

Yamagishi T, Hirose S \& Kondo T 2008 Secondary DNA structure formation for Hoxb9 promoter and identification of its specific binding protein. Nucleic Acids Research 36 1965-1975.

Zebisch A, Staber PB, Delavar A, Bodner C, Hiden K, Fischereder K, Janakiraman M, Linkesch W, Auner HW, Emberger W et al. 2006 Two transforming C-RAF germ-line mutations identified in patients with therapyrelated acute myeloid leukemia. Cancer Research $\mathbf{6 6}$ 3401-3408.

Zhang L, Smit-McBride Z, Pan X, Rheinhardt J \& Hershey JW 2008 An oncogenic role for the phosphorylated h-subunit of human translation initiation factor eIF3. Journal of Biological Chemistry 283 24047-24060.

Zwart W, Rondaij M, Jalink K, Sharp ZD, Mancini MA, Neefjes J \& Michalides R 2009 Resistance to antiestrogen arzoxifene is mediated by overexpression of cyclin D1. Molecular Endocrinology 23 1335-1345. 